\title{
Prevalence and Associated Factors with Anxiety and Depression in Patients with Systemic Lupus Erythematosus in a Moroccan Region
}

\author{
Ibtissam El Harch ${ }^{*}{ }^{\circledR}$, Soumaya Benmaamar ${ }^{1}$, Naoual Oubelkacem², Reda Jennane ${ }^{3}$, \\ Bineta Jho Diagne ${ }^{1}$, Moncef Maiouak ${ }^{1}$, Imad Chakri' ${ }^{1}$, Mohammed Omari' ${ }^{1}$ Nada Otmani ${ }^{1}$, \\ Mohamed Amine Berraho1, Samira El Fakir ${ }^{1}$, Rhizlane Berrady², Nabil Tachfouti1 \\ ${ }^{1}$ Laboratory of Epidemiology, Clinical Research and Community Health, Faculty of Medicine and Pharmacy, Fes, Morocco \\ ${ }^{2}$ Internal Medicine Department, CHU Hassan II, Fes, Morocco \\ ${ }^{3}$ Faculty of Medicine and Pharmacy, Fes, Morocco \\ Email: *elibtissam1@gmail.com
}

How to cite this paper: El Harch, I., Benmaamar, S., Oubelkacem, N., Jennane, R., Diagne, B.J., Maiouak, M., Chakri, I., Omari, M., Otmani, N., Berraho, M.A., El Fakir, S., Berrady, R. and Tachfouti, N. (2022) Prevalence and Associated Factors with Anxiety and Depression in Patients with Systemic Lupus Erythematosus in a Moroccan Region. Open Access Library Journal, 9: e8394. https://doi.org/10.4236/oalib.1108394

Received: January 24, 2022

Accepted: February 25, 2022

Published: February 28, 2022

Copyright $\odot 2022$ by author(s) and Open Access Library Inc.

This work is licensed under the Creative Commons Attribution International License (CC BY 4.0).

http://creativecommons.org/licenses/by/4.0/ (c) (i) Open Access

\begin{abstract}
Systemic lupus erythematosus is a chronic autoimmune disease affecting particularly women and is characterized by diverse symptomatology. the main objective of our work is to assess the risk of anxiety and depression and their associated factors in patients with this disease and this is within the framework of a cross-sectional study carried out in the internal medicine department of CHU Hassan II in Fez. Eligible patients were recruited, informed about the study and invited to participate in order to complete a questionnaire providing information on their personal data and evaluating their psychological state using the Hospital Anxiety and Depression Scale (HADs). Statistical analysis was carried out first descriptive, followed by univariate analysis and finally a multivariate analysis to look for factors that may be associated with the risk of anxiety and depression, taking into account possible confounding factors. For this, we included 102 patients, $92.2 \%$ of which were women with an average age of $41.6 \pm 13.7$ years. $55.4 \%$ (CI 95\%: $45.8 \%$ - 65\%) suffered from anxiety, which was statistically associated with the low level of study (OR $=2.77$; CI 95\%: $1.14-6.74$ ), the large number of comorbidities $(\mathrm{OR}=1.89$; $\mathrm{CI} 95 \%: 1.18-3.03)$ and with the presence of respiratory manifestations ( $\mathrm{OR}=4.14$; CI 95\%: 1.27 - 13.43). Depression was present in $57.4 \%$ (95\% CI: $47.8 \%-67 \%)$, this presence was associated with marriage $(\mathrm{OR}=$ 4.81; CI 95\%: 1.53 - 15.08), low monthly income (OR $=4.44 ; 1.47$ - 13.40), the large number of comorbidities ( $\mathrm{OR}=1.93 ; 1.14-3.28)$ and a high number of lupus manifestations $(\mathrm{OR}=1.33 ; 1.03-1.73)$, hence the need to take into ac-
\end{abstract}


count these disorders and to fight against the factors that cause them.

\section{Subject Areas}

Epidemiology, Global Health, Internal Medicine, Psychiatry \& Psychology

\section{Keywords}

Systemic Lupus Erythematosus, Anxiety, Depression, Hospital Anxiety and Depression Scale, Morocco

\section{Introduction}

Systemic lupus erythematosus (SLE) is a chronic autoimmune disease affecting particularly women and is characterized by diverse symptomatology [1]. It affects 1 to 12 people out of 5000 worldwide [2]. Due to the difficult nature of lupus and its impact on the central nervous system, patients with SLE are more likely to suffer from depression, anxiety or other mental disorders [3].

Neurolupus is a heterogeneous set of neurological and psychiatric syndromes described in $12 \%$ to $95 \%$ of lupus patients [4], of which mood and anxiety disorders are among its most frequent manifestations [5] [6] [7] and can even be considered as the second most common neuropsychiatric syndrome that can be observed in patients with this disease [8]. In addition, the chronic nature of SLE can lead to the development of psychological manifestations such as depression and anxiety, which are two heterogeneous comorbidities that can develop at different stages of the disease [9] [10] and lead to a loss of control over its evolution [11].

Depressive symptomatology remains among the most common complaints in SLE patients [5] [12] despite some disagreement in terms of diagnosis and estimation of its prevalence which varies considerably between cohorts (17\% - 75\%) due to sample heterogeneity and the use of different instruments to detect depressive symptoms [5] [6] [7] [13] [14] [15] [16] [17], but the Hospital Anxiety and Depression Scale (HADS) remains one of the most widely used [18] and its performance has been evaluated and showed a sensitivity of $88.9 \%$, a specificity of $92.6 \%$ and a precision of $92.6 \%$, making the HADS a useful tool for assessing anxiety and depression in these patients [19].

The importance of psychiatric disorders in SLE is not limited to their high prevalence, but also to the possible negative consequences of these manifestations on patients' lives. In this sense, a decrease in health-related quality of life (HRQoL) has been observed in patients with anxiety disorders [20] [21] [22].

In our knowledge, there are no data in Morocco concerning the risk of psychological disorders in patients with SLE. The main objective of our work is to assess the prevalence of anxiety and depression in patients with SLE at CHU Hassan II in Fez and look for the factors that may be associated with the appearance of these disorders. 


\section{Patients and Methods}

\subsection{Patient Population}

\subsubsection{Study and Population}

This is a cross-sectional study carried out in the internal medicine department at CHU Hassan II in Fez. Patients aged 18 years and above who are diagnosed with SLE according to ACR criteria and treated in the internal medicine department were recruited, informed of the study and invited to participate.

\subsubsection{Data Collection}

After having had the agreement of the ethics committee of Sidi Mohamed Ben Abdellah University, Faculty of Medicine and Pharmacy, Fez, Morocco, we recruited the eligibles patients who agreed to participate, after signing a written consent to answer a questionnaire containing information on their socio-demographic characteristics, (age, sex, marital status, level of education and employment status) and their antecedents. Information on the characteristics of the disease such as its duration, different manifestations, autoantibody status (anti-DNA, antinuclear) and types of treatment used was obtained by interviewing patients and examining their medical files. Anxiety and depression were measured using the Hospital anxiety and depression scale (HADS).

Patients with documented intellectual disability, major psychopathology and/ or major neurocognitive disorders were excluded from this study.

\subsection{Hospital Anxiety and Depression Scale (HADS)}

The HADS was developed by Zigmond and Snaith in 1983 to screen for anxiety disorders and depressive syndromes in patients hospitalized in non-psychiatric settings, but it was subsequently validated for outpatient use. This is a self-report scale that identifies anxiety and depressive disorders. It has 14 items marked from 0 to 3 . Seven questions related to anxiety (total A) and seven others related to the depressive dimension (total $\mathrm{D}$ ). For each item, the response is scored from 0 to 3 on a scale depending on the intensity of the symptom during the past week. The range of possible scores, therefore, extends for each subscale from 0 to 21, with the highest scores corresponding to the presence of more severe symptoms. For each subscale (anxiety and depression), cutoff values were determined: a score between 0 and 7 is considered normal, while a score of 8 or higher indicates significant disorder [23] [24].

\subsection{Statistical Analysis}

Descriptive statistics were used to describe the personal, medical and the disease characteristics as well as the prevalence of anxiety and depression; frequencies were used for qualitative variables, while means and standard deviations were used for quantitative variables.

The study of the link between the different factors and the risk of anxiety or depression was carried out using the KHI-2 test or the Fisher test for qualitative variables (sex, marital status, level of education, employment status, comorbid- 
ities, manifestations of the disease and treatment). While the analysis of the quantitative variables was carried out using Student's test and this for the age, the number of comorbidities, the duration of disease progression and the number of lupus manifestations. The significance level was set at 5\%.

Multivariate logistic regression analysis was performed to determine possible factors associated with anxiety and depression taking into account confounding factors. The threshold for inclusion in the logistic regression model was $20 \%$. The significant association was presented using an OR and its confidence interval.

Statistical analysis was performed using the R software.

\section{Results}

\subsection{Personal Characteristics (Table 1)}

In total, 102 patients were collected, $92.2 \%$ of which were women with an average

Table 1. Personal and medical characteristics $(n=102)$.

\begin{tabular}{|c|c|}
\hline Variables & $N(\%)$ Or $M( \pm S D)(N=102)$ \\
\hline Age & $41.64 \pm 13.75$ \\
\hline \multicolumn{2}{|l|}{ Gender } \\
\hline Males & $8(7.8 \%)$ \\
\hline Females & $94(92.2 \%)$ \\
\hline \multicolumn{2}{|l|}{ Level of study $(n=100)$} \\
\hline Low level of study & $50(50 \%)$ \\
\hline High level of study & $50(50 \%)$ \\
\hline \multicolumn{2}{|l|}{ Profession } \\
\hline Unemployed & $74(72.5 \%)$ \\
\hline Employed & $28(27.5 \%)$ \\
\hline \multicolumn{2}{|l|}{ Marital status } \\
\hline Single & $27(26.5 \%)$ \\
\hline Divorced or widowed & $14(13.7 \%)$ \\
\hline Married & $61(59.8 \%)$ \\
\hline \multicolumn{2}{|l|}{ Monthly income $(\mathrm{n}=101)$} \\
\hline$\leq 2000 \mathrm{dhs}$ & $69(68.3 \%)$ \\
\hline$>2000 \mathrm{dhs}$ & $32(31.7 \%)$ \\
\hline \multicolumn{2}{|l|}{ Habitat $(\mathrm{n}=101)$} \\
\hline Urban & $69(68.3 \%)$ \\
\hline Rural & $32(31.7 \%)$ \\
\hline Number of comorbidites & $1.15 \pm 1.08$ \\
\hline Arterial hypertension & $13(12.7 \%)$ \\
\hline Diabetes & $10(9.8 \%)$ \\
\hline Cadiopathy & $10(9.8 \%)$ \\
\hline Nephropathy & $8(7.8 \%)$ \\
\hline Neoplasia & $1(1 \%)$ \\
\hline Abortion $(n=94)$ & $13(13.8 \%)$ \\
\hline Other autoimmune diseases & $13(12.7 \%)$ \\
\hline Other comorbidites & $49(48 \%)$ \\
\hline
\end{tabular}


age of $41.6 \pm 13.7$ years. $68.3 \%$ lived in urban areas, $59.8 \%$ were married and $8.8 \%$ lived alone.

For the antecedents, $12.7 \%$ were hypertensive, $12.7 \%$ had another autoimmune disease and $13.8 \%$ of our female patients have already had at least one abortion.

\subsection{Characteristics of the Disease (Table 2)}

The duration of the disease was estimated on average at $6.8 \pm 5.5$ years. $48 \%$ had general manifestations, $70.6 \%$ had dermatological manifestations, $64.7 \%$ had rheumatological manifestations, 50\% had renal manifestations, $9.8 \%$ had neuropsychic manifestations, $17.6 \%$ had cardiac manifestations and $20.6 \%$ had respiratory manifestations. On average, the number of manifestations of lupus was estimated at $4.47 \pm 1.95$. For the treatment, $56.6 \%$ were on corticosteroid therapy

Table 2. Characteristics of the disease.

\begin{tabular}{|c|c|}
\hline Variables & $\begin{array}{c}N(\%) \text { or } M( \pm S D) \\
\quad(N=102)\end{array}$ \\
\hline Duration of disease & $6.8 \pm 5.5$ \\
\hline General manifestations & $49(48 \%)$ \\
\hline Dermatological manifestations & $72(70.6 \%)$ \\
\hline Facial lesions & $49(48 \%)$ \\
\hline Rheumatological manifestations & $66(64.7 \%)$ \\
\hline Renal manifestations & $51(50 \%)$ \\
\hline Neuropsychic manifestations & $10(9.8 \%)$ \\
\hline Cardiac manifestations & $18(17.6 \%)$ \\
\hline Vascular manifestations & $12(11.8 \%)$ \\
\hline Respiratory manifestations & $21(20.6 \%)$ \\
\hline Digestive manifestations & $12(11.8 \%)$ \\
\hline Ophthalmologic manifestations & $25(24.5 \%)$ \\
\hline Hematological manifestations & $28(27.5 \%)$ \\
\hline Immunological manifestations $(\mathrm{n}=80)$ & $39(48.8 \%)$ \\
\hline Anti-DNA antibodies $(\mathrm{n}=83)$ & $39(47 \%)$ \\
\hline Antinuclear antibodies $(n=84)$ & $17(20.2 \%)$ \\
\hline Number of manifestations of lupus & $4.47 \pm 1.95$ \\
\hline \multicolumn{2}{|l|}{ Type of treatment $(n=99)$} \\
\hline Corticosteroid therapy & $20(20.2 \%)$ \\
\hline Anti-malarial & $23(23.2 \%)$ \\
\hline Corticosteroid therapy + anti-malarial & $56(56.6 \%)$ \\
\hline \multicolumn{2}{|l|}{ Dose of corticosteroid therapy $(n=76)$} \\
\hline$\leq 40 \mathrm{mg}$ & $56(73.7 \%)$ \\
\hline$>41 \mathrm{mg}$ & $20(26.3 \%)$ \\
\hline
\end{tabular}


+ a synthetic antimalarial, $20.2 \%$ were on corticosteroid therapy alone of which $73.7 \%$ had a corticosteroid dose not exceeding $40 \mathrm{mg}$ per day.

\subsection{Anxiety}

More than half of our patients suffered from anxiety 55.4\% (CI 95\%: $45.8 \%$ $65 \%$ ) (Table 3) which was statistically associated with the advanced age, the low level of education, the unemployment, the marriage, the fact of having several antecedents, the long duration of the disease and the presence of respiratory manifestations. The multivariate analysis showed that the risk of anxiety increases with the low level of study, the large number of comorbidities as well as with the presence of respiratory manifestations (Table 4).

Table 3. Anxiety and depression $(n=102)$.

\begin{tabular}{cc}
\hline HADs & Prevalence + CI 95\% \\
\hline Anxiety & $55.4 \%$ \\
& $($ CI 95\%; $45.8 \%-65 \%)$ \\
Depression & $57.4 \%$ \\
& $($ CI $95 \% ; 47.8 \%-67 \%)$ \\
\hline
\end{tabular}

Table 4. Factors associated with anxiety.

\begin{tabular}{|c|c|c|c|c|c|}
\hline \multirow{2}{*}{\multicolumn{2}{|c|}{ Variables }} & \multicolumn{2}{|c|}{ Anxiety } & \multirow{2}{*}{$P$-value } & \multirow{2}{*}{$\begin{array}{c}\text { Adjusted OR + } \\
\text { CI } 95 \%\end{array}$} \\
\hline & & No & Yes & & \\
\hline Age & & $36.56 \pm 12.11$ & $45.84 \pm 13.78$ & 0.001 & \\
\hline \multirow{2}{*}{ Level of study } & $\begin{array}{l}\text { low level of } \\
\text { study }\end{array}$ & $35.6 \%$ & $61.1 \%$ & \multirow{2}{*}{0.015} & $\begin{array}{c}2.77 \\
(1.14-6.74)\end{array}$ \\
\hline & $\begin{array}{l}\text { high level of } \\
\text { study }\end{array}$ & $64.4 \%$ & $38.9 \%$ & & 1 \\
\hline \multirow{2}{*}{ Profession } & Unemployed & $62.2 \%$ & $80.4 \%$ & \multirow{2}{*}{0.048} & \\
\hline & Employed & $37.8 \%$ & $19.6 \%$ & & \\
\hline \multirow{3}{*}{ Marital status } & Single & $42.2 \%$ & $14.3 \%$ & \multirow{3}{*}{0.007} & \\
\hline & $\begin{array}{l}\text { Divorced or } \\
\text { widowed }\end{array}$ & $11.1 \%$ & $16.1 \%$ & & \\
\hline & Married & $46.7 \%$ & $69.6 \%$ & & \\
\hline \multicolumn{2}{|c|}{ Number of comorbidites } & $0.78 \pm 0.79$ & $1.45 \pm 1.2$ & 0.001 & $\begin{array}{c}1.89 \\
(1.18-3.03)\end{array}$ \\
\hline \multirow{2}{*}{$\begin{array}{l}\text { Arterial } \\
\text { hypertension }\end{array}$} & Yes & $2.2 \%$ & $21.4 \%$ & \multirow{2}{*}{0.005} & \\
\hline & No & $97.8 \%$ & $78.6 \%$ & & \\
\hline \multicolumn{2}{|c|}{ Duration of disease } & $5.35 \pm 4.25$ & $7.82 \pm 6.11$ & 0.021 & \\
\hline \multirow{2}{*}{$\begin{array}{l}\text { Respiratory } \\
\text { manifestations }\end{array}$} & Yes & $11.1 \%$ & $28.6 \%$ & \multirow[t]{2}{*}{0.047} & $\begin{array}{c}4.14 \\
(1.27-13.43)\end{array}$ \\
\hline & No & $88.9 \%$ & $71.4 \%$ & & 1 \\
\hline
\end{tabular}




\subsection{Dépression}

For the depression, it was present in 57.4\% (CI 95\%: 47.8\% - 67\%) (Table 3). This presence was associated with the advanced age, marriage, the number of comorbidities as well as the presence of several manifestations linked to lupus disease. Multivariate analysis showed that depression was linked to marriage, to low monthly income, the large number of comorbidities and a high number of manifestations linked to lupus (Table 5).

\section{Discussion}

The main objective of our work was to estimate the prevalence of anxiety and depression in patients with SLE followed in the internal medicine department in the CHU Hassan II in Fes and it has been shown that more than half of our patients suffered from these disorders. This is consistent with the results of several

Table 5. Factors associated with depression.

\begin{tabular}{|c|c|c|c|c|c|}
\hline \multirow{2}{*}{\multicolumn{2}{|c|}{ Variables }} & \multicolumn{2}{|c|}{ Depression } & \multirow{2}{*}{ P-value } & \multirow{2}{*}{$\begin{array}{l}\text { Adjusted OR + } \\
\text { CI } 95 \%\end{array}$} \\
\hline & & No & Yes & & \\
\hline \multicolumn{2}{|l|}{ Age } & $36.7 \pm 12.05$ & $45.41 \pm 13.94$ & 0.001 & \\
\hline \multirow{3}{*}{ Marital status } & Single & $39.5 \%$ & $17.2 \%$ & \multirow{3}{*}{0.035} & 1 \\
\hline & Divorced or widowed & $14.0 \%$ & $13.8 \%$ & & $\begin{array}{c}1.23 \\
(0.28-5.37)\end{array}$ \\
\hline & Married & $46.5 \%$ & $69.0 \%$ & & $\begin{array}{c}4.81 \\
(1.53-15.08)\end{array}$ \\
\hline \multirow[t]{2}{*}{ Monthly income } & $\leq 2000 \mathrm{dhs}$ & $57.1 \%$ & $75.9 \%$ & \multirow[t]{2}{*}{0.054} & $\begin{array}{c}4.44 \\
(1.47-13.40)\end{array}$ \\
\hline & $>2000 \mathrm{dhs}$ & $42.9 \%$ & $24.1 \%$ & & 1 \\
\hline \multicolumn{2}{|c|}{ Number of comorbidites } & $0.79 \pm 0.83$ & $1.41 \pm 1.19$ & 0.003 & $1.93(1.14-3.28)$ \\
\hline \multirow{2}{*}{$\begin{array}{l}\text { Arterial } \\
\text { hypertension }\end{array}$} & Yes & $2.3 \%$ & $20.7 \%$ & \multirow{2}{*}{0.006} & \\
\hline & No & $97.7 \%$ & $79.3 \%$ & & \\
\hline \multirow{2}{*}{ Diabetes } & Yes & $2.3 \%$ & $15.5 \%$ & \multirow{2}{*}{0.041} & \\
\hline & No & $97.7 \%$ & $84.5 \%$ & & \\
\hline \multirow{2}{*}{ Cadiopathy } & Yes & $2.3 \%$ & $15.5 \%$ & \multirow{2}{*}{0.041} & \\
\hline & No & $97.7 \%$ & $84.5 \%$ & & \\
\hline \multicolumn{2}{|c|}{ Duration of disease } & $5.49 \pm 4.48$ & $7.63 \pm 5.99$ & \multicolumn{2}{|l|}{0.056} \\
\hline \multirow{2}{*}{$\begin{array}{l}\text { Cardiac } \\
\text { manifestations }\end{array}$} & Yes & $7.0 \%$ & $24.1 \%$ & \multirow{2}{*}{0.031} & \\
\hline & No & $93.0 \%$ & $75.9 \%$ & & \\
\hline \multirow{2}{*}{$\begin{array}{l}\text { Respiratory } \\
\text { manifestations }\end{array}$} & Yes & $7.0 \%$ & $31.0 \%$ & \multirow{2}{*}{0.005} & \\
\hline & No & $93.0 \%$ & $69.0 \%$ & & \\
\hline \multicolumn{2}{|c|}{ Number of lupus manifestations } & $3.81 \pm 1.74$ & $4.95 \pm 1.99$ & 0.003 & $\begin{array}{c}1.33 \\
(1.03-1.73)\end{array}$ \\
\hline
\end{tabular}


studies which have shown a high prevalence of its disorders in lupus patients and that this prevalence was much higher than those observed in the general population [22] [25] as well as in other rheumatic and connective tissue diseases [26] [27] [28]. Similarly, in a recent systematic review and meta-analysis of 59 studies, Zhang et al. estimated the prevalence of depression and anxiety in adults with SLE, and showed that the prevalence of anxiety alone varied between $4 \%$ and $85 \%$ in individual studies, while the meta-analysis revealed a prevalence of $40 \%$; CI $95 \%(30 \%-49 \%)$ according to the HADS. For depression, estimates ranged from $2 \%$ to $91.7 \%$ in the individual studies while the meta-analysis revealed a prevalence of $30 \%$; CI $95 \%$ (22\% - 38\%) according to HADS [18], these observed differences could be explained by the difference in the time periods during which these studies were performed, the characteristics of the disease during each study, as well as the social and cultural background of the participants.

This fairly high frequency of these disorders has prompted several researchers to look for the cause most involved in the onset of anxiety and depression in lupus patients and they were able to conclude that the presence of certain genes such as the FKBP5 gene could be responsible for the onset of psychological disorders in SLE patients [29] or other chronic diseases [30]. Thus, a study showed that this FKBP5 gene was involved in the response to antidepressants [31]. For anxiety and although studies are scarce in this direction, but some reports have indicated that it is also associated with the presence of the FKBP5 gene [32] [33].

Despite these suggestions, no confirmation has been reported for the involvement of the FKBP5 gene in the appearance of psychological disorders in patients with lupus, hence the interest in looking for other factors that may be implicated, and in this context Waheed et al. found that in patients with chronic rheumatic diseases, educational attainment was associated with anxiety and depression, while marital status, gender, employment and monthly income had no effect on the frequency of anxiety and depression [34], but a Chinese study that looked at patients with SLE found that in these patients, education, unemployment and low monthly income were associated with anxiety and depression [22]. In the same sense, several other studies have confirmed the association between the risk of anxiety and depression and low monthly income in patients with SLE [35] [36] [37], this is consistent with our results which showed that unemployment and low education level were associated with anxiety and that low monthly income was strongly associated with depression. For marital status, our study showed a strong association between marriage and the risk of depression, this was also found in a Saudi study [38] which proved that marriage was associated with presence of moderate to severe depressive mood in lupus patients. These results differ from other studies where the risk of mental disorders was more frequent in single patients [37] [39], this discrepancy can be explained by the role of family support in this type of patient and which can, depending on its absence or existence, be considered as a protective or stimulating factor of men- 
tal disorders in patients with SLE. In this sense, Chin et al. have shown that having a partner who does not provide you with psychological support may be a cause of an increased risk of developing psychological manifestations in patients with SLE [40]. Thereby, a Japanese study carried out on ambulatory women with SLE showed that problems in human relationships and in particular family relationships can have a negative influence on mental health and can even increase the risk of suicidal thoughts [39].

In our study, the long duration of the disease was associated with the risk of psychological disorders, which was also reported in Saudi lupus patients [38].

Several studies have linked disease activity to the risk of depression [14] [22] [37] [41] [42] [43] [44], which is consistent with our results where the risk of anxiety increased with the increase in the number of lupus manifestations. Thus, respiratory manifestations increase the risk of anxiety this has not been reported in the different studies and this discrepancy can be explained by the fact that our study was carried out for the most part during the COVID19 pandemic which made the respiratory manifestations more anxious for fear of infection by the Corona virus. With regard to the neurological impairment of lupus, our study was unable to demonstrate an association between anxiety and/or depression and this type of manifestation, which differs from the results of other studies where neurolupus was incriminated in the presence of these psychological disorders in SLE patients [45] [46], this discrepancy can be explained by the low prevalence of neurolupus in our study population.

Thus, the results of a Russian study [47] confirm that the risk of mental disorders increases with the presence of comorbidities in patients diagnosed with SLE, this is in agreement with the results of our study which concluded that the risk of anxiety and depression increases with the increase in the number of co-morbidities.

Our study is the first in Morocco to estimate the prevalence of anxiety and depression in patients with SLE and its conclusion that $55.4 \%$ of patients suffer from anxiety and $57.4 \%$ are depressed, implies that anxiety and depression are common ailments that deserve to be researched in this type of patients although the scale used for this assessment is a self-assessment scale which may partially limit our results.

\section{Conclusions}

The results of our study showed that more than half of patients with SLE suffer from psychological disorders. The prevalence of anxiety was estimated at $55.4 \%$ (95\% CI: $45.8 \%$ - 65\%) while depression was at 57.4\% (95\% CI: 47.8\% - 67\%), and that these disorders are associated mainly with the low socio-economic level, the presence of other comorbidities as well as the presence of manifestations of lupus.

These results are alarming and should encourage clinicians to:

○ Systematically look for these disorders in this type of patient. 
○ To try to fight against the factors which can be responsible.

○ To study the possibility of the integration of psychological care systematic of these patients.

\section{Conflicts of Interest}

We have no conflicts of interest.

\section{References}

[1] Cervera, R., Khamashta, M.A., Font, J., Sebastiani, G.D., Gil, A., Lavilla, P., Mejía, J.C., Aydintug, A.O., Chwalinska-Sadowska, H., de Ramón, E., Fernández-Nebro, A., Galeazzi, M., Valen, M., Mathieu, A., Houssiau, F., Caro, N., Alba, P., RamosCasals, M., Ingelmo, M., Hughes, G.R.V. and European Working Party on Systemic Lupus Erythematosus (2003) Morbidity and Mortality in Systemic Lupus Erythematosus during a 10-Year Period: A Comparison of Early and Late Manifestations in a Cohort of 1,000 Patients. Medicine (Baltimore), 82, 299-308. https://doi.org/10.1097/01.md.0000091181.93122.55

[2] Ghodke-Puranik, Y. and Niewold, T.B. (2015) Immunogenetics of Systemic Lupus Erythematosus: A Comprehensive Review. Journal of Autoimmunity, 64, 125-136. https://doi.org/10.1016/j.jaut.2015.08.004

[3] Figueiredo-Braga, M., Cornaby, C., Cortez, A., Bernardes, M., Terroso, G., Figueiredo, M., Mesquita, C.D.S., Costa, L. and Poole, B.D. (2018) Depression and Anxiety in Systemic Lupus Erythematosus: The Crosstalk between Immunological, Clinical, and Psychosocial Factors. Medicine (Baltimore), 97, e11376. https://doi.org/10.1097/MD.0000000000011376

[4] Govoni, M., Bortoluzzi, A., Padovan, M., Silvagni, E., Borrelli, M., Donelli, F., Ceruti, S. and Trotta, F. (2016) The Diagnosis and Clinical Management of the Neuropsychiatric Manifestations of Lupus. Journal of Autoimmunity, 74, 41-72. https://doi.org/10.1016/j.jaut.2016.06.013

[5] Palagini, L., Mosca, M., Tani, C., Gemignani, A., Mauri, M. and Bombardieri, S. (2013) Depression and Systemic Lupus Erythematosus: A Systematic Review. Lupus, 22, 409-416. https://doi.org/10.1177/0961203313477227

[6] Iverson, G.L., Sawyer, D.C., McCracken, L.M. and Kozora, E. (2001) Assessing Depression in Systemic Lupus Erythematosus: Determining Reliable Change. Lupus, 10, 266-271. https://doi.org/10.1191/096120301680416959

[7] Bachen, E.A., Chesney, M.A. and Criswell, L.A. (2009) Prevalence of Mood and Anxiety Disorders in Women with Systemic Lupus Erythematosus. Arthritis \& Rheumatology, 61, 822-829. https://doi.org/10.1002/art.24519

[8] Seawell, A.H. and Danoff-Burg, S. (2005) Body Image and Sexuality in Women with and without Systemic Lupus Erythematosus. Sex Roles, 53, 865-876. https://doi.org/10.1007/s11199-005-8298-y

[9] Hawro, T., Krupińska-Kun, M., Rabe-Jabłońska, J., Sysa-Jędrzejowska, A., Robak, E., Bogaczewicz, J. and Woźniacka, A. (2011) Psychiatric Disorders in Patients with Systemic Lupus Erythematosus: Association of Anxiety Disorder with Shorter Disease Duration. Rheumatology International, 31, 1387-1391. https://doi.org/10.1007/s00296-010-1689-6

[10] Kwan, A., Katz, P. and Touma, Z. (2019) The Assessment of Anxiety and Depression and Its Associated Factors in SLE. Current Rheumatology Reviews, 15, 90-98. https://doi.org/10.2174/1573397114666180926101513 
[11] McElhone, K., Abbott, J., Shelmerdine, J., Bruce, I.N., Ahmad, Y., Gordon, C., Peers, K., Isenberg, D., Ferenkeh-Koroma, A., Griffiths, B., Akil, M., Maddison, P. and The, L.-S. (2007) Development and Validation of a Disease-Specific HealthRelated Quality Of Life Measure, the LupusQol, for Adults with Systemic Lupus Erythematosus. Arthritis \& Rheumatology, 57, 972-979.

https://doi.org/10.1002/art.22881

[12] Kozora, E., Ellison, M.C. and West, S. (2006) Depression, Fatigue, and Pain in Systemic Lupus Erythematosus (SLE): Relationship to the American College of Rheumatology SLE Neuropsychological Battery. Arthritis \& Rheumatology, 55, 628-635. https://doi.org/10.1002/art.22101

[13] Ainiala, H., Loukkola, J., Peltola, J., Korpela, M. and Hietaharju, A. (2001) The Prevalence of Neuropsychiatric Syndromes in Systemic Lupus Erythematosus. Neurology, 57, 496-500. https://doi.org/10.1212/WNL.57.3.496

[14] Zakeri, Z., Shakiba, M., Narouie, B., Mladkova, N., Ghasemi-Rad, M. and Khosravi, A. (2012) Prevalence of Depression and Depressive Symptoms in Patients with Systemic Lupus Erythematosus: Iranian Experience. Rheumatology International, 32, 1179-1187. https://doi.org/10.1007/s00296-010-1791-9

[15] Nery, F.G., Borba, E.F., Viana, V.S.T., Hatch, J.P., Soares, J.C., Bonfá, E. and Neto, F.L. (2008) Prevalence of Depressive and Anxiety Disorders in Systemic Lupus Erythematosus and Their Association with Anti-Ribosomal P Antibodies. Progress in Neuro-Psychopharmacology \& Biological Psychiatry, 32, 695-700.

https://doi.org/10.1016/j.pnpbp.2007.11.014

[16] Sanna, G., Bertolaccini, M.L., Cuadrado, M.J., Laing, H., Khamashta, M.A., Mathieu, A. and Hughes, G.R.V. (2003) Neuropsychiatric Manifestations in Systemic Lupus Erythematosus: Prevalence and Association with Antiphospholipid Antibodies. The Journal of Rheumatology, 30, 985-992.

[17] Andrade, A.B. and Bosi, M.L.M. (2015) Qualidade do cuidado em dois centros de atenção psicossocial sob o olhar de usuários1. Saúde e Sociedade, 24, 887-900. https://doi.org/10.1590/S0104-12902015131949

[18] Zhang, L., Fu, T., Yin, R., Zhang, Q. and Shen, B. (2017) Prevalence of Depression and Anxiety in Systemic Lupus Erythematosus: A Systematic Review and MetaAnalysis. BMC Psychiatry, 17, Article No. 70. https://doi.org/10.1186/s12888-017-1234-1

[19] de Almeida Macêdo, E., Appenzeller, S. and Lavras Costallat, L.T. (2017) Assessment of the Hospital Anxiety and Depression Scale (HADS) Performance for the Diagnosis of Anxiety in Patients with Systemic Lupus Erythematosus. Rheumatology International, 37, 1999-2004. https://doi.org/10.1007/s00296-017-3819-x

[20] Mirabelli, G., Cannarile, F., Bruni, C., Vagelli, R., De Luca, R. and Carli, L. (2015) One Year in Review 2015: Systemic Lupus Erythematosus. Clinical and Experimental Rheumatology, 33, 414-425.

[21] Yilmaz-Oner, S., Oner, C., Dogukan, F.M., Moses, T.F., Demir, K., Tekayev, N., Yilmaz, N., Tuglular, S. and Direskeneli, H. (2015) Anxiety and Depression Predict Quality of Life in Turkish Patients with Systemic Lupus Erythematosus. Clinical and Experimental Rheumatology, 33, 360-365.

[22] Shen, B., Tan, W., Feng, G., He, Y., Liu, J., Chen, W., Huang, X., Da, Z., Xu, X., Liu, H. and Gu, Z. (2013) The Correlations of Disease Activity, Socioeconomic Status, Quality of Life, and Depression/Anxiety in Chinese Patients with Systemic Lupus Erythematosus. Clinical and Developmental Immunology, 2013, Article ID: 270878. https://doi.org/10.1155/2013/270878 
[23] Zigmond, A.S. and Snaith, R.P. (1983) The Hospital Anxiety and Depression Scale. Acta Psychiatrica Scandinavica, 67, 361-370. https://doi.org/10.1111/j.1600-0447.1983.tb09716.x

[24] Botega, N.J., Bio, M.R., Zomignani, M.A., Garcia Junior, C. and Pereira, W.A.B. (1995) Transtornos do humor em enfermaria de clínica médica e validaçäo de escala de medida (HAD) de ansiedade e depressäo. Revista de Saúde Pública, 29, 355-363. https://doi.org/10.1590/S0034-89101995000500004

[25] Greco, C.M., Kao, A.H., Sattar, A., Danchenko, N., Maksimowicz-McKinnon, K.M., Edmundowicz, D., Sutton-Tyrrell, K., Tracy, R.P., Kuller, L.H. and Manzi, S. (2009) Association between Depression and Coronary Artery Calcification in Women with Systemic Lupus Erythematosus. Rheumatology (Oxford), 48, 576-581. https://doi.org/10.1093/rheumatology/kep020

[26] Stubbs, B., Aluko, Y., Myint, P.K. and Smith, T.O. (2016) Prevalence of Depressive Symptoms and Anxiety in Osteoarthritis: A Systematic Review and Meta-Analysis. Age Ageing, 45, 228-235. https://doi.org/10.1093/ageing/afw001

[27] Zhang, L., Xia, Y., Zhang, Q., Fu, T., Yin, R., Guo, G., Li, L. and Gu, Z. (2017) The Correlations of Socioeconomic Status, Disease Activity, Quality of Life, and Depression/Anxiety in Chinese Patients with Rheumatoid Arthritis. Psychology, Health \& Medicine, 22, 28-36. https://doi.org/10.1080/13548506.2016.1198817

[28] Westhoff, G., Dörner, T. and Zink, A. (2012) Fatigue and Depression Predict Physician Visits and Work Disability in Women with Primary Sjögren's Syndrome: Results from a Cohort Study. Rheumatology, 51, 262-269. https://doi.org/10.1093/rheumatology/ker208

[29] Lou, Q.-Y., et al. (2021) Associations of FKBP4 and FKBP5 Gene Polymorphisms with Disease Susceptibility, Glucocorticoid Efficacy, Anxiety, Depression, and HealthRelated Quality of Life in Systemic Lupus Erythematosus Patients. Clinical Rheumatology, 40, 167-179.

https://ink.springer.com/article/10.1007/s10067-020-05195-0

[30] Shinozaki, G., et al. (2011) Relationship between FKBP5 Polymorphisms and Depression Symptoms among Kidney Transplant Recipients. Depression and Anxiety, 28, 1111-1118.

[31] Binder, E.B., Salyakina, D., Lichtner, P., Wochnik, G.M., Ising, M., Pütz, B., Papiol, S., Seaman, S., Lucae, S., Kohli, M.A., Nickel, T., Künzel, H.E., Fuchs, B., Majer, M., Pfennig, A., Kern, N., Brunner, J., Modell, S., Baghai, T., Deiml, T., Zill, P., Bondy, B., Rupprecht, R., Messer, T., Köhnlein, O., Dabitz, H., Brückl, T., Müller, N., Pfister, H., Lieb, R., Mueller, J.C., Lõhmussaar, E., Strom, T.M., Bettecken, T., Meitinger, T., Uhr, M., Rein, T., Holsboer, F. and Muller-Myhsok, B. (2004) Polymorphisms in FKBP5 Are Associated with Increased Recurrence of Depressive Episodes and Rapid Response to Antidepressant Treatment. Nature Genetics, 36, 1319-1325. https://doi.org/10.1038/ng1479

[32] Roberts, S., Keers, R., Breen, G., Coleman, J.R.I., Jöhren, P., Kepa, A., Lester, K.J., Margraf, J., Scheider, S., Teismann, T., Wannemüller, A., Eley, T.C. and Wong, C.C.Y. (2019) DNA Methylation of FKBP5 and Response to Exposure-Based Psychological Therapy. American Journal of Medical Genetics Part B: Neuropsychiatric Genetics, 180, 150-158. https://doi.org/10.1002/ajmg.b.32650

[33] Hirakawa, H., Akiyoshi, J., Muronaga, M., Tanaka, Y., Ishitobi, Y., Inoue, A., Oshita, H., Aizawa, S., Masuda, K., Higuma, H., Kanehisa, M., Ninomiya, T. and Kawano, Y. (2016) FKBP5 Is Associated with Amygdala Volume in the Human Brain and Mood State: A Voxel-Based Morphometry (VBM) Study. International Journal of Psychiatry in Clinical Practice, 20, 106-115. 
https://doi.org/10.3109/13651501.2016.1144772

[34] Waheed, A., Hameed, K., Khan, A.M., Syed, J.A. and Mirza, A.I. (2006) The Burden of Anxiety and Depression among Patients with Chronic Rheumatologic Disorders at a Tertiary Care Hospital Clinic in Karachi, Pakistan. Journal of Pakistan Medical Association, 56, 243-247.

[35] Meszaros, Z.S., Perl, A. and Faraone, S.V. (2012) Psychiatric Symptoms in Systemic Lupus Erythematosus: A Systematic Review. Journal of Clinical Psychiatry, 73, 9931001. https://doi.org/10.4088/JCP.11r07425

[36] Trupin, L., Tonner, M.C., Yazdany, J., Julian, L.J., Criswell, L.A., Katz, P.P. and Yelin, E. (2008) The Role of Neighborhood and Individual Socioeconomic Status in Outcomes of Systemic Lupus Erythematosus. The Journal of Rheumatology, 35, 1782-1788.

[37] Xie, X., Wu, D. and Chen, H. (2016) Prevalence and Risk Factors of Anxiety and Depression in Patients with Systemic Lupus Erythematosus in Southwest China. Rheumatology International, 36, 1705-1710. https://doi.org/10.1007/s00296-016-3559-3

[38] Alsowaida, N., Alrasheed, M., Mayet, A., Alsuwaida, A. and Omair, M.A. (2018) Medication Adherence, Depression and Disease Activity among Patients with Systemic Lupus Erythematosus. Lupus, 27, 327-332. https://doi.org/10.1177/0961203317725585

[39] Ishikura, R., Morimoto, N., Tanaka, K., Kinukawa, N., Yoshizawa, S., Horiuchi, T., Nakashima, H. and Otsuka, T. (2001) Factors Associated with Anxiety, Depression and Suicide Ideation in Female Outpatients with SLE in Japan. Clinical Rheumatology, 20, 394-400. https://doi.org/10.1007/s100670170002

[40] Chin, C.N., Cheong, I. and Kong, N. (1993) Psychiatric Disorder in Malaysians with Systemic Lupus Erythematosus. Lupus, 2, 329-332. https://doi.org/10.1177/096120339300200510

[41] Walker, S.E., Smarr, K.L., Parker, J.C., Weidensaul, D.N., Nelson, W. and McMurray, R.W. (2000) Mood States and Disease Activity in Patients with Systemic Lupus Erythematosus Treated with Bromocriptine. Lupus, 9, 527-533. https://doi.org/10.1177/096120330000900709

[42] Nery, F.G., Borba, E.F., Hatch, J.P., Soares, J.C., Bonfá, E. and Neto, F.L. (2007) Major Depressive Disorder and Disease Activity in Systemic Lupus Erythematosus. Clinical Rheumatology, 48, 14-19. https://doi.org/10.1016/j.comppsych.2006.04.002

[43] Karol, D.E., Criscione-Schreiber, L.G., Lin, M. and Clowse, M.E.B. (2013) Depressive Symptoms and Associated Factors in Systemic Lupus Erythematosus. Psychosomatics, 54, 443-450. https://doi.org/10.1016/j.psym.2012.09.004

[44] Julian, L.J., Gregorich, S.E., Tonner, C., Yazdany, J., Trupin, L., Criswell, L.A., Yelin, E. and Katz, P.P. (2011) Using the Center for Epidemiologic Studies Depression Scale to Screen for Depression in Systemic Lupus Erythematosus. Arthritis Care \& Research (Hoboken), 63, 884-890. https://doi.org/10.1002/acr.20447

[45] Hanly, J.G., Fisk, J.D., McCurdy, G., Fougere, L. and Douglas, J.-A. (2005) Neuropsychiatric Syndromes in Patients with Systemic Lupus Erythematosus and Rheumatoid Arthritis. The Journal of Rheumatology, 32, 1459-1456.

[46] Hanly, J.G., Su, L., Farewell, V., McCurdy, G., Fougere, L. and Thompson, K. (2009) Prospective Study of Neuropsychiatric Events in Systemic Lupus Erythematosus. The Journal of Rheumatology, 36, 1449-1459. https://doi.org/10.3899/jrheum.081133 
[47] Lisitsyna, T.A., Vel'tishchev, D.I., Seravina, O.F., Kovalevskaia, O.B., Marchenko, A.S., Novikova, D.S., Novikov, A.A., Aleksandrova, E.N. and Nasonov, E.L. (2009) Prevalence of Mental Disorders in SLE Patients: Correlations with the Disease Activity and Comorbid Chronic Conditions. Terapevticheskii Arkhiv, 81, 10-16. 